\title{
Grapari Information Technology Service Analysis of Telkomsel Salatiga Using ITIL V3 Domain Service Operation
}

\author{
Daniel Albert Santoso ${ }^{1}$, Agustinus Fritz Wijaya*2 \\ 1,2 Information System Departement, Satya Wacana Christian University \\ Email:1682017007@student.uksw.edu, 2agustinus.wijaya@uksw.edu
}

\begin{abstract}
Parameters for the success of IT in a company or organization are IT services to users in order to support the fulfillment of the business goals of a company or organization. Therefore, information technology has become a major requirement for companies or organizations. Operating IT services in a company or organization cannot be without problems. To find out the extent to which IT services are running and the extent of management in managing and handling incidents and problems in IT service companies, an analysis and assessment of IT services is needed. This research proposes the ITIL framework version 3 (Information Technology Infrastructure Library) with the Service Operation domain to review IT service practices. The results of this study indicate several recommendations including increasing the number of resources who are experts in the IT field, so that any obstacles that arise in the application can be resolved immediately. It is hoped that by carrying out this research, GraPARI can reduce these obstacles and can work optimally.
\end{abstract}

Keywords: Analysis, ITSM, ITIL, Service Operation.

\section{INTRODUCTION}

Now information technology is increasingly advanced and has received recognition and place by the world because almost all aspects of human life use information technology. The flow of information encourages technological progress to be faster and almost unstoppable because it is not limited to space and time. Today, Information Technology (IT) is one of the existing technologies that is developing very fast. The role of IT (Information Technology) in supporting human performance in carrying out daily tasks starting from individuals, groups, small organizations to large organizations, to government and private organizations is increasingly being recognized [2]. The development and advancement of information technology has changed humans in the way they complete all their jobs [1]. People who do business need information technology for the purposes of their work, one of which is service to customers / the public. Information technology service management is widely used for the 
purposes of managing public services using information technology. Technology services are of the utmost concern in information technology management activities, especially for the purpose of auditing these services. Audit of information technology services can be a bridge for the development and sustainability of a company [16].

GraPARI now has more than 20 employees and owns and implements services using information technology for its supporters. GraPARI is a Telkomsel customer service center. Apart from acting as a customer service center that focuses on serving its customers, GraPARI also provides sales of its own products such as kartuHALO and simPATI. GraPARI can serve all types of complaints related to starter packs, such as activation of forfeited cards, complaints about lost numbers, registration of new numbers, number transfers, and many more. The process of these services is handled by customer service using the DSC (Digital Smart Care) application, a customer value application. Meanwhile, the number transfer process is only run using the CRM (Customer Relationship Management) and Paradise applications which can only be used by IT staff. The use of this application is not only for changing numbers but being able to track the location of the SIM card number, check credit, get SIM card user data if it is really needed and must obtain permission from the person concerned and there must be a signature on the stamp.

With this application, it is necessary to have a variety of supporters for GraPARI such as human resources in accordance with the criteria for company needs, software and supporting hardware. Information technology can create higher business value if the management of the company is in accordance with internationally implemented standards, one of which is the ITIL (Information Technology Infrastructure Library). Of the many kinds of frameworks related to the discussion of information technology, the most frequently used are the ITIL (Information Technology Infrastructure Library) framework and COBIT (Control Objective for Information and related Technology). ITIL or Information Technology Infrastructure Library, is the result of findings and developments from the Office of Government Commerce (OGC) in England in the form of a framework [6]. ITIL can assist organizations or companies in implementing information technology to be an added value for the company or organization because it can be said to be international standard best practice [10]. With the data to be processed and data analysis carried out, the authors decide in this study, the authors will analyze the quality of IT service management by focusing on Service Operations which refers to the Information Technology Infrastructure Library V3 (ITIL V3) framework with a case study: GraPARI Salatiga office. 


\section{METHODS}

\subsection{Method of Collecting Data}

Based on the description above, this study aims to analyze Information Technology services at GraPARI Salatiga. This research is a research that uses qualitative methods with field studies and literature studies. Field studies were carried out through interviews with the employees or employees concerned, and observations were carried out by researchers themselves in order to observe the daily work processes at the GraPARI company on October 28, 2019. This interview data was in the form of raw data which was then processed. The interview was conducted for one day with a resource person, namely Mr. Andy as an IT staff at GraPARI and as a user of DSC, CRM, and Customer Value applications.

\subsection{Research Stages}

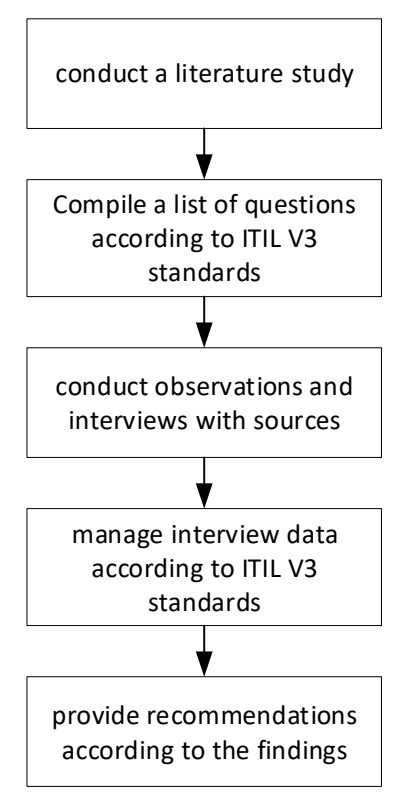

Figure 1. Research Stages

The initial steps carried out in accordance with the picture are preliminary. This stage was carried out before starting the research to analyze the problems experienced by GraPARI Salatiga. Then the literature study was carried out, in the literature study the author collected several journals related to the ITIL V3 framework or other related matters that will be discussed in this journal. 
Information can be used as a reference for carrying out the discussion in this journal with further study. By studying previous research to get an overview related to the discussion, namely the analysis of IT service management using the ITIL V3 framework in the Service Operations domain, the Service Operation domain has five processes in it, namely event management, incident management, problem management, fullfillment requests and access management.

The next stage is planning and designing. Compile a list of questions based on the guidance from the Service Operation domain. The third stage is the data collection process. This stage is carried out using qualitative methods. Interviews were conducted with resource persons related to IT services at GraPARI. Interviews are one of the methods or methods that are classified as the most frequently used during field studies, by asking several questions directly or indirectly with the informants. With this method, it is expected to be able to obtain and ensure the data obtained is valid and can be processed into information by the author. Interviews were conducted with employees related to the research written. In the observation at this stage, the authors make direct observations and records at the company and admin who use the system [1].

The fourth stage is analyzing the data. Data that has been collected from the results of interviews and observations can be processed using the ITIL V3 service operation framework to analyze the problems faced and how to handle each problem [11]. In the data analysis carried out, there are findings where these findings are GraPARI's deficiencies or weaknesses in implementing IT services. The final stage of this research is to provide recommendations related to the findings, the stage of determining the preparation of recommendations to get an understanding of the findings and implement recommendations that are useful to improve previous results [7]. So that it can improve performance and make IT services at GraPARI even better. This ITIL domain Service Operation has various benefits when implemented, such as ensuring quality and standardization of service, customer satisfaction, return on investment, control of financial contributions and several other benefits. Study of literature: - Analysis, according to $\mathrm{KBBI}$, analysis is an investigation of an event (fabrication, deed, etc.) to find out the real situation (causes, issues, and so on). - Information Technology Service Management or ITSM (Information Technology Service Management) is a method of managing an information technology (IT) system that is philosophically centered on the perspective of IT service consumers on corporate businesses or government institutions [9]. At this time, many companies have used ITSM to encourage businesses to be even better. Therefore, a good knowledge is needed about managing information technology services itself so that IT management can be done properly. 
How to maintain a balance between the technology service business in several ITSM processes, namely: 1. Information in accordance with what the customer needs 2. Serving with quality IT and at a price that matches the effectiveness of the given IT 3. Fostering good cooperation between suppliers and customers by not disappointing each other and being able to provide the best service 4 . Fostering and serving with the best level of service capabilities, which later can affect the level of satisfaction obtained by the customer / customer. Management of information technology services is needed by almost all parties, starting from individual users, management users, non-IT units and top management. In this case, individual users are employees who must be served by the IT unit. Therefore, companies must be able to determine who is entitled to service from the IT unit [14]. - ITIL (Information Technology Infrastructure Library) is a general framework that describes best practices and IT Service Management (ITSM). ITIL provides guidance for service providers in supporting the provision of quality IT services and processes, functions and other capabilities required. ITIL is used by many organizations and offers best practice guidelines that are generally accepted for all organizations providing services. [8] Some of the benefits provided by ITIL are increasing service availability, increasing the use of resource management, increasing time to market for new products and services, increasing user and customer satisfaction with IT services, directly leading to increased business profits and revenue, saving finances through reduced rework, improve decision making and risk is optimized [3]. ITIL is built around five main components in the ITIL Service Lifecycle.

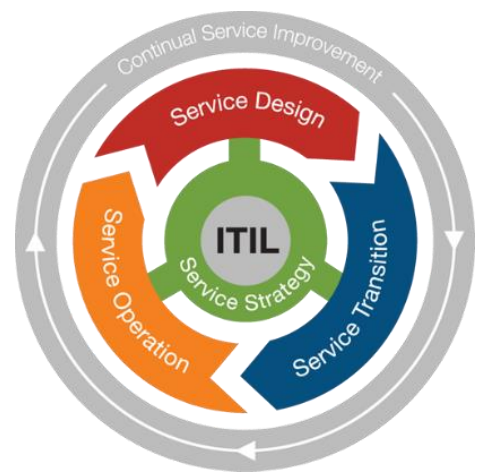

Figure 2. ITIL Service Lifecycle

The following is a description of the five ITIL components, namely:

1) Service Stratregy, provides guidance for ITSM implementation on how to view the ITSM concept not only as an organizational capability (providing, managing and operating IT services), but also as a company's strategic 
asset. This guide is presented in the form of the basic principles of the ITSM concept, references and core processes that operate throughout all stages of the ITIL Service Lifecycle [5].

2) Service Design provides guidance to IT organizations systematically and best practices in designing and building IT services and implementing ITSM itself. Service Design contains design principles and methods for converting strategic goals of IT and business organizations into IT service portfolios / collections and service assets such as servers, storage and so on. The scope of Service Design is not only designing new IT services, but also changing processes and improving service quality, service continuity and service performance [4].

3) Service Transition provides guidance for IT organizations to be able to develop the ability to change the design results of IT services, both new and customized IT services into a new environment or IT services whose specifications are changed into an operational environment. This lifecycle stage provides an illustration of how a need defined in the Service Strategy is then formed in Service Design to be effectively realized in Service Operations [4].

4) Service Operation, which is a lifecycle stage that includes all daily operational activities for managing IT services. Inside there are various guides on how to manage IT services efficiently and effectively and ensure the level of performance that has been promised with previous violations. These guides cover how to maintain the operational stability of IT services and manage changes in the design, scale, scope and performance targets of IT services [4].

5) Continual Service Improvement contains important guidelines in preparing and maintaining the quality of service from the design process, transition and operation. CSI combines various principles and methods of quality management. [4] - Service Operation (SO) is one of the phases of the ITIL framework. In ITILV2, SO is included in the service support category. The focus on ITILV2 is for alignment between IT and business, where the management process is divided into two major parts, namely Service Support and Service Delivery. Service Support focuses on day-to-day activities, while Service Delivery focuses on planning services that will be provided to customers. Whereas in the ITILV3 framework, where ITILV3 focuses on business and IT integration, SO is a separate phase in addition to the Service Strategic (SS), Service Design (SD), Service Transition (ST) and Continual Service Improvement (CSI) phases [15].

A list of questions:

1) Do you have a procedure / SOP in operating the computer?

2) Does it have a procedure / SOP in operating the application used? 
3) Is there a manual regarding the operation of the application used?

4) Is there a regular backup of data?

5) Is there a backup system security administrator?

6) What applications does Grapari Telkomsel Salatiga have?

7) Does the system have their respective privileges to avoid unknown users?

8) Does the system have security (for example: VPN, SSL)?

9) Is there a time limit for operating the application?

10) Do you have antivirus on the computer that is used to access the application?

11) Do you have a history of running the application (for example: when to access, who is the user who accessed it)

12) Is there a person in charge for the server and application?

13) Does the application used have fast, accurate, and precise output results?

14) Is there a security in the form of input made by employees on the application being used?

15) Does it have documentation if there are problems with management?

\section{RESULTS AND DISCUSSION}

CRM is an application provided by Grapari Telkomsel to facilitate service to customers. Customer relationship management (CRM) is a strategy on how to optimize profitability through good relationships with customers and customer satisfaction [11]. The purpose of using the DSC application, customer value application, and others is to make it easier for customer service to input data for every customer who has a complaint about their SIM card or wants to register about Telkomsel. With just one media, people can get adequate service.

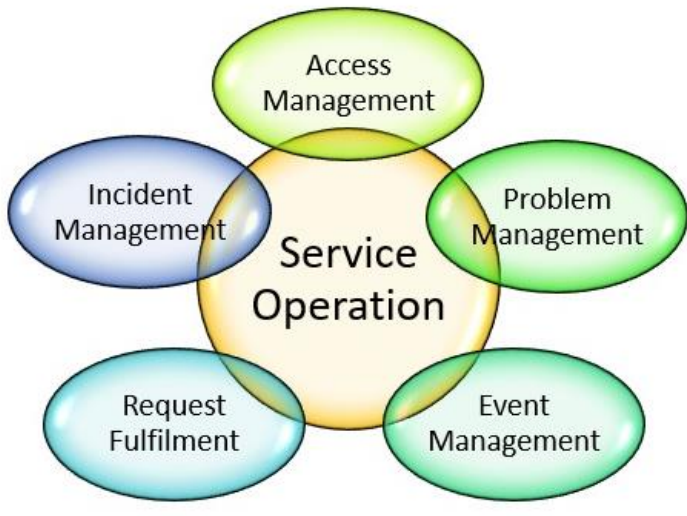

Figure 3. Service Operation 


\subsection{Event Management}

Event Management is management to monitor, survey and evaluate all events that occur in the IT infrastructure to regularly review IT performance in order to track and improve preparation for unexpected events [12]. So far GraPARI has been monitoring the application on a regular basis, has also had and implemented SOPs to operate the application. GraPARI Salatiga has implemented event management by monitoring services. By monitoring the application regularly, every event can be evaluated and the possibility that it will occur can be prevented.

\subsection{Incident Management}

Incident Management is the process of restoring or repairing damaged services. The purpose of incident management is to return services to normal as quickly as possible, and to minimize the adverse impact on business operations [13]. Based on the interview conducted with Mr. Andy, any maintenance, or the network being in trouble during working hours can hinder the service process because the application cannot operate. Apart from maintenance, the IT service process at GraPARI was also hampered due to blackouts or power outages. However, GraPARI Salatiga has taken care of this by having several generators ready to use if needed and a UPS installed on every computer in the GraPARI Salatiga office.

\subsection{Problem Management}

Problem Management is the stage of analysis to solve problems that occur and find the cause so that the problem does not repeat itself in the future [10]. The DSC application has been used by TELKOMSEL for several years to make it easier to serve customers. But still, you cannot avoid problems that arise such as bugs that must be fixed immediately. The importance of documenting when a problem occurs is very important so that problems that have occurred can be recorded neatly if at any time the same problem occurs and the causes and solutions can be found [10]. The GraPARI Salatiga office has carried out the problem management stage. GraPARI Salatiga has insurance obtained from central telkomsel, which in the event of damage, a ticket is made to be submitted to the head office. It's just that there aren't resources to handle it directly.

\subsection{Request Fulfilment}

Request Fulfilment is a service request process according to user needs. The purpose of Request Fulfillment is to enable users to request and receive service 
standards, to source and provide these services, to provide information to users and customers about services and procedures for obtaining them, and to assist with general information, complaints and comments [13]. GraPARI Salatiga has implemented request fulfillment stages, in order to always serve customer desires and make customers feel satisfied with the services provided.

\subsection{Access Management}

Access Management is the process of granting access rights to service users so that the service is not misused by unauthorized parties [10]. TELKOMSEL has created a system where every employee who has an account for the DSC application can only access according to their position which will have their own User Interface (UI), thereby minimizing the misuse of applications and data in the application. DSC applications can be accessed nationally using the internet which already has Secure Socket Layer (SSL) security. The application used also has its own operating hours, starting from 07.00-18.00, after which the application will be off. Information that is entered in the application will automatically be backed up and stored in a central database that can be accessed anywhere, so that if there is a problem with the application at GraPARI Telkomsel Salatiga, customers can carry out activities related to Telkomsel services at other GraPARI offices.

Findings:

Do not have human resources as technicians or IT experts in the office. so, it requires help from the center when problems occur with the application. It will take some time to fix.

Recommendation:

Each GraPARI office has a dedicated IT expert to fix the application if a problem occurs.

\section{CONCLUSION}

Based on the results of data analysis from IT service management in the CSR, DCS, and customer value applications using the ITIL V3 domain service operation, the service system is quite good. It's just that there is a lack of human resources in the IT field to fix if there are problems with the application. 


\section{REFERENCES}

[1] Robin Huang1, Ivanrezki Ngadijaya2, "Analisa Tata kelola teknologi informasi pada PT. BJMS dengan Framework ITIL Versi 3 Domain Service Operation", 2019.

[2] SURYADI PEBRIYARI PUTRA, "ANALISIS PENGELOLAAN LAYANAN TI PADA DOMAIN SERVICE OPERATION DENGAN MENGGUNAKAN FRAMEWORK ITIL V3 (STUDI KASUS DANA PENSIUN TELKOM)" , 2016.

[3] Hendra Lesmana Putra 1, Eko Darwiyanto, ST.,MT. 2 , Gede Agung Ary Wisudiawan, S.Kom., MT. 3, "Audit Infrastruktur Teknologi Informasi Berbasis ITIL V.3 Domain Service Operation pada FMS Departemen Engineering PT. Grand Indonesia" , 2015.

[4] Letisya Soumeru, "Analisis Manajemen Layanan Teknologi Informasi Menggunakan Framework ITIL V.3 DomainService Operation (Studi Kasus : PT.Telekomunikasi Indonesia, Tbk. Semarang)" , 2016.

[5] Jefriana, "FRAMEWORK ITIL V3 DOMAIN SERVICE OPERATION DALAM ANALISIS PENGELOLAAN TEKNOLOGI BLENDED LEARNING “, 2018.

[6] Luki Aisha Kusuma Wardani1), Murahartawaty2), Luthfi Ramadani3)," Perancangan Tata Kelola Layanan Teknologi Informasi Menggunakan ITIL versi 3 Domain Service Transition Dan Service Operation Di Pemerintah Kota Bandung ", 2016.

[7] kresna Anggi Sakti S, Heru Pramono Hadi, SE, M.Kom, ANALISIS TINGKAT KEMATANGAN SISTEM SERVICE DESK KEPEGAWAIAN BERDASRAKAN FRAMEWORK ITIL V3 KANTOR BADAN KEPEGAWAIAN DAERAH PROVINSI JAWA TENGAH

[8] Faried Effendya, , Bahana Sukma Dewab , Eva Hariyanti c, "Problem Management Teknologi Informasi Berdasarkan Kerangka Kerja ITIL V3 dan COBIT 5" , 2018.

[9] Shofa Shofia Hilabi dan Baenil Huda, "LAYANAN TEKNOLOGI INFORMASI E-GOVERNMENT MENGGUNAKAN FRAMEWORK INFORMATIONTECHNOLOGY INFRASTRUCTURE LIBRARY V.3 (ITIL V.3) DOMAINSERVICE TRANSITION (STUDI KASUS PEMDA KABUPATEN KARAWANG) ", 2019.

[10] Meylinda Ayu Pratiwi, dan Andeka Rocky Tanaamah, " Analysis of IT Service Management of Salatigaku Application using Information Techonology Infrastructure Library (ITIL) V3 Framework ", 2020.

[11] Dodi Putra Sirait, "PENGARUH CUSTOMER RELATIONSHIP MANAGEMENT DAN KUALITAS PELAYANAN TERHADAP KEPUASAN 
PELANGGAN" ( The Effect of Relationship Management and Service Quality on Customer Satisfaction), 2018.

[12] P. J. Sahuleka and A. D. Manuputty, "Analisis Kualitas Layanan Teknologi Informasi dengan Menggunakan Framework Information Technology Infrastructure Library Version 3 (ITIL V.3) Service Operation (Studi Kasus PT. PLN (Persero) Distribusi Jateng \& DIY).," Fakultas Teknologi Informasi, Universitas Kristen Satya Wacana, 2016.

[13] itSMF, An Introductory Overview of ITIL V3, IT Service Management Forum Limited, 2007.

[14] A ARDIANSYAH, "Analisis dan Perancangan Manajemen Layanan Teknologi Informasi Menggunakan IT Infrastructure Library Versi 3 (ITILV3) Domain Service Operation" , 2018.

[15] Husniteja Sukmana, persiapan implementasi iTOP (Bagian ke-2) , 2016

[16] Didin Herlinudinkhaji, "Evaluasi Layanan Teknologi Informasi ITIL Versi 3 Domain Service Design pada Universitas Selamat Sri Kendal” , 2019. 